INTUISI 12 (1) (2020)
INTUISI
JURNAL PSIKOLOGI ILMIAH
http://journal.unnes.ac.id/nju/index.php/INTUISI
Terindeks DOAJ: 2541-2965

\title{
TERAPI KOGNITIF PERILAKU UNTUK MENURUNKAN POTENSI KEKAMBUHAN PADA NARAPIDANA MANTAN PECANDU NARKOBA
}

\author{
Ni Luh Krishna Ratna Sari ${ }^{1 \bowtie}$ Hamidah $^{1}$, Adijanti Marheni ${ }^{2}$
}

${ }^{1}$ Fakultas Psikologi, Universitas Airlangga, Indonesia

${ }^{2}$ Program Studi Psikologi, Fakultas Kedokteran, Universitas Udayana, Indonesia

\begin{tabular}{l}
\hline Info Artikel \\
\hline Sejarah Artikel: \\
Disubmit 3 Desember 2019 \\
Direvisi 20 Januari 2020 \\
Diterima 24 Maret 2020 \\
\end{tabular}

Keywords:

Cognitive Behavioral

Therapy, Relapse

\begin{abstract}
Abstrak
Peredaran narkoba tidak hanya terjadi di berbagai tempat umum, namun juga di dalam suatu lembaga pemasyarakatan. Bagi narapidana yang merupakan mantan pecandu narkoba di lembaga pemasyarakatan, hal ini dapat mempengaruhi potensi mengalami kekambuhan yang menjadi semakin tinggi. Salah satu upaya yang dapat dilakukan untuk menurunkan potensi mengalami kekambuhan adalah dengan pemberian terapi kognitif perilaku. Tujuan dari penelitian ini adalah menguji efektivitas terapi kognitif perilaku untuk menurunkan potensi kekambuhan pada narapidana mantan pecandu narkoba di salah satu lembaga pemasyarakatan di Bali. Penelitian ini menggunakan metode kuantitatif ekperimen dengan one group pretest-posttest design. Teknik sampling yang digunakan adalah pusposive sampling. Data dianalisis menggunakan uji beda Wilcoxon signed-rank test. Hasil penelitian menunjukkan nilai negative ranks $=3$ dengan nilai $\mathrm{Z}=-1.604$ dan Asymp. Sig. $=0.109$ ( $\mathrm{p}>0.05)$. Hal ini berarti tidak ada perbedaan yang signifikan potensi kekambuhan narapidana mantan pecandu narkoba di lembaga pemasyarakatan sebelum dan setelah diberikan terapi kognitif perilaku. Meskipun begitu, angka negative ranks menunjukkan bahwa seluruh skor posttest lebih rendah dari skor pretest sehingga dapat disimpulkan bahwa terapi kognitif perilaku dapat menurunkan potensi kekambuhan pada narapidana mantan pecandu narkoba di lembaga pemasyarakatan.
\end{abstract}

\begin{abstract}
Drug trafficking not only occurs in various public places but also in prison. For the former drug addicts prisoners, this can affect the potential of relapse to become even higher. One effort to reduce the potential of relapse is by giving cognitive behavioral therapy. The purpose of this study was to examine the effectiveness of cognitivebehavioral therapy to reduce the potential of relapse in former drug addicts at one of the prisons in Bali. This study uses quantitative methods with one group pretest-posttest design. The sampling technique used is purposive sampling. Data were analyzed using a Wilcoxon signed-rank test. The results showed the value of negative ranks $=3$ with $Z$ values $=-1.604$ and Asymp. Sig. $=0.109$ ( $p>0.05)$. It means there is no significant difference in the potential relapse of the former drug addicts prisoners before and after cognitive-behavioral therapy program. However, negative ranks score indicates that all of the posttest scores are lower than the pretest score. So it can be concluded that cognitive-behavioral therapy can reduce the potential of relapse in former drug addicts prisoners.
\end{abstract}

(C) 2020 Universitas Negeri Semarang

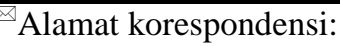

Fakultas Psikologi, Universitas Airlangga, Kampus B UNAIR

Jl. Airlangga 4-6, Surabaya (60286)
}

p-ISSN 2086-0803

krishnaratnasari-16@psikologi.unair.ac.id 


\section{PENDAHULUAN}

Kasus penyalahgunaan narkoba merupakan salah satu masalah kompleks dan marak terjadi di Indonesia. Hal ini terlihat dari angka kasus penyalahgunaan narkoba di Indonesia menunjukkan peningkatan selama beberapa tahun terakhir. Data survei didapatkan bahwa pada tahun 2009 sebanyak 5064 orang melakukan penyalahgunaan narkoba, diikuti data pada tahun 2012 yang menunjukkan peningkatan yaitu 10.451 orang, dan data terakhir pada tahun 2017 menunjukkan sebanyak 13.155 orang yang melakukan penyalahgunaan berbagai jenis narkoba (BNN, 2017).

Tingginya angka penyalahgunaan narkoba juga dapat diakibatkan karena akses yang mudah untuk mendapatkan narkoba. Peredaran tidak hanya terjadi di tempat hiburan malam akan tetapi juga merambah pada daerah pemukiman, sekolah-sekolah, kampus, bahkan dilingkungan rumah tangga. Peredaran narkoba tidak hanya terjadi di berbagai tempat umum, tetapi juga masuk ke lembaga pemasyarakatan termasuk di salah satu lembaga pemasyarakatan di Bali. Hal ini diketahui dari beberapa berita yang memuat bahwa terdapat beberapa narapidana bahkan tenaga sipir yang menjadi tersangka penggelapan narkoba ke dalam lapas dan menerima pasokan narkoba untuk dijual keluar lapas (Kelana, 2017; Candra, 2018).

Kasus penyalahgunaan narkoba di dalam lapas sangat banyak ditemui, hal ini dikarenakan akses untuk membeli maupun mendapatkan narkoba secara gratis. Hasil survei dari BNN (2014) juga menunjukkan bahwa sekitar $88 \%$ akses narkoba dipenjara diperoleh dari teman sesama narapidana, 27\% dari teman diluar penjara, $16 \%$ dari petugas lapas, $9 \%$ dari bandar diluar penjara, dan $2 \%$ dari pacar atau pasangan.

Situasi tersebut tentunya menjadi tantangan besar bagi narapidana yang sedang berusaha untuk mengurangi maupun berhenti menggunakan narkoba sehingga adanya kemungkinan untuk mengalami kekambuhan atau relapse sangat tinggi. Kekambuhan atau relapse merupakan kembalinya seseorang pada pola perilaku menggunakan narkoba (Marlatt \& Donovan, 2005). Periode kekambuhan dapat terjadi beberapa minggu maupun beberapa bulan sebelum akhirnya individu memutuskan untuk mengkonsumsi narkoba (Melemis, 2015).

Banyak faktor yang dapat menyebabkan seseorang mengalami kekambuhan, mulai dari faktor lingkungan seperti kekayaan, berbagai situasi sosial, paparan terhadap stres, konflik interpersonal, pergaulan, dan faktor intrapersonal atau dari dalam individu sendiri termasuk keyakinan untuk dapat mengontrol diri termasuk pikiran, perasaan, dan perilaku yang berkaitan dengan penggunaan narkoba (Blume, 2005).

Peneliti melakukan studi pendahuluan dengan teknik wawancara pada salah seorang narapidana di salah satu lembaga pemasyarakatan. Berikut hasil kutipan wawancancara studi pendahuluan dengan seorang narapidana mantan pengguna narkoba:

"Gimana ya mbak, kalo kayak saya ini bisa sih bisa berhenti karena memang ada keinginan. Tapi ya susah juga, ya pas kita keliling jalan-jalan ke sel lain trus liat orang-orang lagi pake ya pasti ada keinginan untuk ikut disana apalagi diajakin kan ditawarin. Ya yang namanya pecandu kalo sudah berhenti pastii pasti pikiran membayangkan dulu pas pake gimana rasanya pasti muncul, apalagi kalo kita disini gak mau kerja diem terus bosen mumet, ya gampang aja buat akhirnya pake lagi kan..jadi ya disini tantangannya, kalo kita bisa mengalihkan ya aman-aman aja, kalo nggak ya sudah".

Pernyataan dari narapidana tersebut sesuai dengan hasil penelitian yang dilakukan 
Sahu \& Sahu (2012) yang menyatakan bahwa salah faktor penting yang dapat meningkatkan risiko penggunaan narkoba adalah faktor sosial yang terdiri dari tekanan lingkungan atau kelompok, adanya role model atau seseorang yang ditiru, dan suatu acara atau kegiataan perayaan.

Hasil wawancara narapidana tersebut juga menyebutkan bahwa sulit untuk mengatasi pikiran atau bayangan yang muncul terkait pengalaman saat menggunakan narkoba. Ditambah lagi karena kurangnya aktivitas yang dapat dilakukan di lembaga pemasyarakatan sehingga mudah merasa bosan serta pikiran untuk mencari dan menggunakan narkoba akan menjadi lebih sering muncul dan mengganggu. Hal ini sesuai dengan hasil penelitian Melemis (2015) yang menyatakan bahwa ketika seseorang mengalami kecanduan, maka sulit untuk menghapus ingatan mengenai hal tersebut. Salah satu cara yang dapat digunakan untuk mengatasinya adalah melatih keterampilan koping yang baik sehingga dapat mengatasi pikiran-pikiran untuk kembali menggunakan narkoba (Witkiewitz \& Marlatt, 2005).

Hasil penelitian Jafari, et.al. (2010) menemukan bahwa dengan meningkatkan keterampilan koping, individu akan mampu untuk mengkonfrontasi berbagai gejala kekambuhan baik secara kognisi, emosi, maupun perilaku sehingga dapat menurunkan atau mencegah terjadinya kekambuhan tersebut. Hal ini juga sesuai dengan hasil wawancara dengan salah satu pengguna narkoba terkait pengalamannya mengalami kekambuhan. Narapidana tersebut menyatakan:

"Sebenernya udah lama sih
berhenti sekitar dua
bulanan..lebih lah.. Saya juga
sibuk sekarang yaa adalah usaha
sedikit biar ada pemasukan. Ya
tadi itu saya jual jus jadi alatnya
saya beli sendiri. Ya lumayan ada
kegiatan juga. Tapi 2 minggu lalu

pake sabu lagi itu waktu lagi ada masalah dirumah. Waktu itu malem saya telpon kerumah biasa kan nanyain kondisi orangtua. Jadi orangtua saya gak tau saya dipenjara, taunya saya di bali kerja. Nah pas telpon itu mama saya bilang kondisi ayah saya lagi kurang bagus jadi dirawat dirumah sakit. Yah.. udah..saya disini gak bisa ngapangapain. Susah susah banget".

Pernyataan tersebut menunjukkan bahwa saat individu tidak memiliki cara yang tepat menghadapi masalahnya, maka kemungkinan untuk mengalami kekambuhan menjadi semakin tinggi. Individu cenderung berpikir bahwa mereka tidak sanggup untuk menghentikan atau mengurangi penggunaan narkoba karena berada pada lingkungan yang dengan bebas menggunakan narkoba dan menganggap bahwa pemulihan sangat berat untuk dilakukan.

Kemampuan individu untuk menggunakan strategi koping yang efektif dalam menghadapi berbagai situasi-situasi yang berisiko menjadi salah satu faktor yang juga memengaruhi kemungkinan terjadinya kekambuhan (Marlatt \& Donovan, 2005). Untuk itu dibutuhkan strategi yang dapat diterapkan pada narapidana pengguna narkoba di lembaga pemasyarakatan yang dapat membantu mencegah terjadinya kekambuhan atau relapse.

Pada narapidana di salah satu lembaga pemasyarakatan di Bali ini, mereka sudah berada pada tahap pemeliharaan perilaku sehingga yang dibutuhkan saat ini adalah strategi yang dapat membantu mereka terhindar dari kekambuhan. Tahap pemeliharaan perilaku merupakan tahapan dimana individu sudah menyadari bahwa dirinya mengalami ketergantungan dan telah berusaha untuk berhenti dengan melakukan aktivitas atau kegiatan kearah perubahan yang lebih positif (Gutierrez \& Czerny, 2017). 
Narapidana di lembaga pemasyarakatan ini dikatakan berada pada tahap pemeliharaan dikarenakan mereka yang selama di penjara memiliki pekerjaan tetap untuk membantu staff kepegawaian di lembaga pemasyarakatan baik di bidang administrasi maupun pelayanan kesehatan. Selain itu, mereka juga memiliki hasil tes urine negatif yang artinya tidak sedang menggunakan narkoba jenis amfetamine, morfin, dan ganja. Hasil tes urine dari pemeriksaan laboratorium dapat dijadikan sebagai bukti bahwa individu menggunakan narkoba atau tidak (Isnawangsari, Riaditya, \& Setiawan, 2015). Hasil penelitian Rambe (2017) juga menyebutkan bahwa pemeriksaan urine yang menunjukkan hasil positif membuktikan individu adalah pengguna narkoba, begitu juga sebaliknya yaitu hasil negatif membuktikan individu bukan pengguna narkoba.

Kekambuhan umumnya dapat dicegah melalui berbagai macam pendekatan tergantung pada permasalahan yang dialami oleh individu. Program pencegahan kekambuhan merupakan suatu program yang tepat untuk mempertahankan perubahan perilaku (Marlatt \& Donovan, 2005). Dalam program pencegahan kekambuhan, individu atau klien diminta berkomitmen untuk melaksanakan program perencanaan perilaku spesifik untuk berubah, misalnya berhenti merokok atau berhenti dari narkoba (Marlatt \& Donovan, 2005).

Pencegahan kekambuhan merupakan suatu program manajemen diri atau selfmanagement yang dirancang untuk meningkatkan kemampuan individu untuk mempertahankan kondisi mereka yang sudah berhenti menggunakan narkoba (Marlatt \& Donovan, 2005). Hasil penelitian menemukan bahwa program pencegahan kekambuhan untuk kasus penyalahgunaan narkoba secara efektif dapat menurunkan kecanduan dan mengurangi penggunaan narkoba
(Handershot, Witkiewitz, George, \& Marlatt, 2011).

Tujuan dari program pencegahan kekambuhan adalah mengajarkan individu untuk mengatasi permasalahan yang menyangkut kondisi kambuh tersebut (Marlatt \& Donovan, 2005). Individu dibantu untuk menyadari sinyal-sinyal akan terjadinya kekambuhan serta diajarkan beberapa keterampilan untuk mencegah terjadinya kekambuhan (Melemis, 2015).

Pada kasus penyalahgunaan narkoba, umumnya program pencegahan kekambuhan yang digunakan adalah penanganan dengan pendekatan kognitif-perilaku. Program ini fokus pada tahap maintenance atau pemeliharaan dari perubahan perilaku kecanduan yang ditunjukkan individu. Terdapat dua tujuan utama dari program ini yaitu (1) mencegah terjadinya kemerosotan atau kemunduran awal atau pertama setelah berkomitmen untuk berubah, dan (2) mencegah berbagai kemerosotan awal yang dapat semakin meningkat dan mengarah pada kekambuhan berulang kali (Marlatt \& Donovan, 2005).

Penelitian ini bertujuan untuk mengetahui efektivitas terapi kognitif perilaku efektif untuk menurunkan potensi kekambuhan pada narapidana mantan pecandu narkoba.

Manfaat dari penelitian ini adalah memperkaya literatur terkait intervensi untuk mencegah dan mengurangi potensi mantan pecandu narkoba mengalami kekambuhan. Hipotesis dalam penelitian ini adalah "terapi kognitif perilaku efektif untuk menurunkan potensi kekambuhan pada narapidana mantan pecandu narkoba di lembaga pemasyarakatan.

\section{METODE}

Teknik sampling yang digunakan adalah pusposive sampling yaitu pengambilan sampel dengan pertimbangan tertentu (Sugiyono, 2010). Kriteria sample dalam penelitian ini adalah: (1) narapidana di salah satu lembaga pemasyarakatan di Bali yang memiliki riwayat 
penyalahgunaan narkoba; (2) sedang berada pada fase pemulihan maintanance atau pemeliharaan perilaku; (3) tidak sedang mengikuti intervensi psikologis; dan (4) menerima intervensi psikologis dalam setting kelompok yang dibuktikan dengan mengisi lembar informed consent. Pada awalnya terdapat 5 orang narapidana yang memenuhi kriteria tersebut, namun 2 diantaranya tidak bersedia untuk berpartisipasi, sehingga jumlah subjek dalam penelitian ini adalah 3 orang.

Penelitian ini menggunakan metode quasiexperiment dengan non-randomized one group pretest-posttest design (Neuman, 2007). Pada desain ini, pengukuran dilakukan sebelum dan setelah pemberian perlakuan atau intervensi.

Tabel 1

Desain Penelitian One Gorup Pretest-posttest Design

\begin{tabular}{ccc}
\hline Pretest & Treatment & Posttest \\
\hline $\mathrm{T} 1$ & $\mathrm{X}$ & $\mathrm{T} 2$ \\
\hline
\end{tabular}

Keterangan:

T1: pengukuran awal sebelum diberikan perlakuan dengan skala AWARE (Advance Warning of Relapse)

$\mathrm{X}$ : pemberian perlakuan yaitu terapi kognitif perilaku

T2: pengukuran akhir setelah diberikan perlakuan dengan skala AWARE (Advance Warning of Relapse)

Variabel bebas dalam penelitian ini adalah terapi kognitif perilaku. Terapi kognitif perilaku merupakan pendekatan terapeutik yang bertujuan untuk menggantikan keyakinan maladaptif individu menjadi lebih adaptif, dan mengajarkan individu keterampilan untuk menghadapi berbagai situasi yang menekan.

Variabel tergantung dalam penelitian ini adalah kekambuhan. Kekambuhan artinya kembalinya individu pada kondisi awal, jika dalam konteks penyalahgunaan narkoba maka kekambuhan berarti kembalinya individu menggunakan narkoba setelah beberapa waktu bertahan dalam kondisi pulih atau berhenti menggunakan narkoba.
Perlakuan atau intervensi yang diberikan dalam penelitian ini adalah terapi kognitif perilaku. Terapi yang diberikan mengacu pada 5 tahapan terapi kognitif perilaku bagi individu dengan riwayat penyalahgunaan narkoba (Range \& Mathias, 2012) yang dibagi menjadi 5 sesi terapi. Pada sesi pertama (1) dilakukan kegiatan pembukaan dan perkenalan yang bertujuan untuk membangun rasa nyaman antara partisipan serta memberikan pemahaman mengenai prosedur keseluruhan kegiatan.

Pada sesi kedua (2) difokuskan pada tema coping with craving yaitu mengidentifikasi faktor-faktor atau triggers yang dapat menimbulkan dorongan untuk kembali menggunakan narkoba, serta mendiskusikan strategi untuk mengatasi dorongan tersebut sehingga terhindar dari kekambuhan. Sesi berikutnya (3) adalah cognitive restructuring yaitu mengidentifikasi dan menggantikan pikiran atau keyakinan negatif yang mengarah pada kembalinya menggunakan narkoba menjadi keyakinan yang lebih rasional dan adaptif.

Dilanjutkan dengan sesi (4) yaitu latihan relaksasi yang bertujuan untuk mengajarkan keterampilan yang bisa diterapkan saat mengalami kecemasan, kesulitan tidur dan lainnya dalam kehidupan sehari-hari, serta sesi terakhir (5) adalah terminasi yaitu evaluasi keseluruhan rangkaian kegiatan serta mendiskusikan komitmen untuk menjaga kondisi saat ini yang berhenti menggunakan narkoba.

Instrumen yang digunakan dalam penelitian ini adalah observasi, wawancara, hasil pengisian skala, dan hasil pengerjaan lembar kerja atau tugas. Evaluasi dilakukan dengan mengintegrasikan hasil dari seluruh instrumen tersebut. Variabel tergantung yang diukur dalam penelitian ini adalah potensi mengalami kekambuhan. Tinggi rendahnya potensi individu mengalami kekambuhan ini diukur menggunakan skala Advance Warning of Relapse atau disingkat AWARE. Skala ini terdiri dari 28 aitem dengan menggunakan 
skala likert (skor 1-7) dan memiliki nilai koefisien reliabilitas sebesar 0.913 (Miller \& Harris, 2000). Semakin tinggi skor yang diperoleh individu maka semakin tinggi potensi individu tersebut akan mengalami kekambuhan atau relapse.

Tabel 2

Kategorisasi Skor Total Skala AWARE

\begin{tabular}{ll}
\hline Kategori & Skor Total \\
\hline Rendah & $28-84$ \\
Sedang & $85-141$ \\
Tinggi & $142-196$ \\
\hline
\end{tabular}

Analisis data yang dilakukan dalam penelitian ini adalah analisis uji beda yang bertujuan untuk mengetahui perbedaan kondisi antara sebelum dan sesudah diberikannya perlakuan atau intervensi. Kondisi ini diukur dengan membandingkan rata-rata nilai pretest dan posttest yang kemudian menunjukkan hasil perbedaan yang signifikan atau tidak. Analisis statistik yang digunakan adalah analisis nonparametrik uji beda wilcoxon signed rank test.

\section{HASIL DAN PEMBAHASAN}

Tabel 3

Hasil Signed Ranks
Pada penelitian ini data kuantitatif yang dihasilkan adalah skor pretest dan posttest skala AWARE (advance warning of relapse) yang menggambarkan potensi subjek mengalami kekambuhan atau relapse. Terdapat 3 kategori untuk menggambarkan kemungkinan relapse pada subjek yaitu kategori rendah (skor 28-84), sedang (skor 85141), dan tinggi (skor 142-196). Semakin tinggi skor yang diperoleh maka semakin tinggi potensi subjek mengalami kekambuhan.

Sebelum diberikan perlakuan, ketiga subjek memiliki skor pada kategori sedang yaitu 99, 106, dan 87. Setelah mendapatkan perlakuan/intervensi, ketiga subjek mengalami penurunan skor yaitu 77, 83, 80 yang masuk pada kategori rendah.

Langkah selanjutnya adalah melakukan uji hipótesis. Hasil uji hipótesis dengan wilcoxon signed ranks test menunjukkan perbedaan potensi kekambuhan pada narapidana, sebelum dan setelah diberikannya perlakuan, serta signifikansi dari perbedaan skor tersebut.

\begin{tabular}{llrrr}
\hline & \multicolumn{4}{c}{ Ranks } \\
\hline Posttest - Pretest & N & Mean Rank & Sum of Ranks \\
& Negative Ranks & $3^{\mathrm{a}}$ & 2.00 & 6.00 \\
& Positive Ranks & $0^{\mathrm{b}}$ & .00 & .00 \\
& Ties & $0^{\mathrm{c}}$ & & \\
& Total & 3 & & \\
\end{tabular}
a. Posttest $<$ Pretest
b. Posttest $>$ Pretest
c. Posttest $=$ Pretest

Data pada Tabel 3 menunjukkan bahwa nilai rerata posttestlebih rendah dari nilai rerata pretest (negative ranks) yang berarti bahwa terdapat terdapat penurunan potensi subjek mengalami kekambuhan setelah diberikan perlakuan atau terdapat perubahan kondisi subjek antara sebelum dan setelah diberikan perlakuan.

Selanjutnya terdapat hasil signifikansi dari perbedaan skor sebelum dan setelah diberikannya perlakuan, dilihat dari tabel 4. 
Tabel 4

Hasil Perhitungan Statistik

\begin{tabular}{lc}
\multicolumn{2}{c}{${\text { Test } \text { Statistics }^{b}}^{b}$} \\
\hline $\mathrm{Z}$ & Posttest - Pretest $^{\mathrm{a}}$ \\
\hline Asymp. Sig. (2-tailed) & $-1.604^{\mathrm{a}}$ \\
\hline
\end{tabular}

a. Based on positive ranks.

b. Wilcoxon Signed Ranks Test

Tabel 4 menunjukkan nilai $\mathrm{Z}=-1.604$ dengan nilai Asymp. Sig $=0.109$ lebih besar dari 0.05 ( $p>0.05)$. Dapat disimpulkan bahwa tidak ada pengaruh yang signifikan dari intervensi atau perlakuan yang telah diberikan.

Tujuan dari penelitian ini adalah untuk mengetahui efektivitas dari pemberian terapi kognitif perilaku dalam menurunkan potensi kekambuhan pada narapidana mantan pecandu narkoba di salah satu lembaga pemasyarakatan di Bali. Hasil analisis menunjukkan bahwa pemberian terapi kognitif perilaku tidak efektif untuk menurunkan potensi kekambuhan mengkonsumsi narkoba pada narapidana. Namun, jika dilihat dari perbedaan rerata skor pretest dan posttest terjadi penurunan skor, meskipun tidak signifikan. Dengan kata lain, perubahan potensi kekambuhan pada narapidana tidak signifikan antara sebelum dan setelah diberikan intervensi terapi kognitif perilaku. Hasil penelitian ini sejalan dengan hasil studi meta-analisis yang dilakukan oleh Irvin, Bowers, Dunn, \& Wang (1999) yang menemukan bahwa pemberian perlakuan untuk relapse prevention dapat memberikan perubahan bagi individu, namun tidak secara signifikan jika dilakukan pengukuran langsung setelah intervensi diberikan.

Salah satu faktor yang dapat membuat narapidana mantan pecandu narkoba di lembaga pemasyarakatan kesulitan untuk menurunkan potensi kekambuhan secara signifikan adalah faktor dukungan sosial yang diperoleh. Dukungan sosial atau keluarga menjadi salah satu penentu bagi mantan pecandu narkoba untuk terhindar dari mengalami kekambuhan, mereka yang memiliki dukungan keluarga positif akan termotivasi untuk melakukan pemulihan (Riandini \& Nurmaguphita, 2017). Berdasarkan hasil wawancara dengan ketiga subjek ditemukan bahwa mereka memiliki konflik baik dengan orangtua maupun anggota keluarga masing-masing sehingga tidak menjalin komunikasi yang baik dan tidak mendapatkan dukungan secara positif.

Penelitian ini memiliki ancaman validitas internal, yaitu history. Selama proses intervensi, terdapat beberapa pengalaman personal dari subjek penelitian yang dapat mempengaruhi efek dari pemberian intervensi. Seorang subjek sempat memiliki konflik dengan kedua orangtuanya tepat sebelum pemberian intervensi, sehingga hal ini mempengaruhi intervensi yang diberikan menjadi kurang efektif. Pengalaman personal lain juga dapat mempengaruhi kurang efektifnya intervensi adalah pengalaman pribadi seperti mendapatkan penolakan saat mengajukan remisi (pengurangan masa hukuman) yang membuat subjek kecewa dan stres. Seperti yang disebutkan Taylor \& Asmundson (2007) bahwa history atau pengalaman subjek penelitian mengenai masalah yang berhubungan dengan eksperimen, yang dalam hal ini adalah masalah yang memicu kekambuhan juga dapat mempengaruhi efektivitas intervensi yang diberikan. Masalah ini berpengaruh ketika dialami subjek ditengah proses eksperimen.

Interaksi dari mantan pecandu narkoba di lembaga pemasyarakatan ini juga terbatas atau lebih sering dilakukan dengan narapidana dengan latar belakang yang sama sehingga 
sulit menghindari potensi alami kekambuhan. Hal ini didukung oleh hasil penelitian Habibi, Basri, \& Rahmadhani (2016) yang menemukan bahwa individu yang lebih banyak menghabiskan waktu dengan sesama mantan pecandu narkoba akan semakin sulit untuk mempertahankan kondisi pulih atau bebas dari narkoba.

Seperti yang telah disebutkan bahwa hasil uji hipotesis menunjukkan bahwa pemberian perlakuan tidak berpengaruh secara signifikan, namun tetap ada penurunan potensi kekambuhan yang dialami oleh subjek penelitian. Hal ini dapat dibuktikan dari rerata skor posttest yang lebih kecil dari rerata skor pretest, hasil observasi, lembar kerja yang telah diisi subjek selama pemberian intervensi, dan hasil wawancara dengan subjek penelitian.

Melalui intervensi terapi kognitif perilaku, subjek penelitian dilatih untuk menyadari situasi-situasi yang menimbulkan dorongan menggunakan narkoba kembali, menyusun rencana untuk menghadapinya berdasarkan pengalaman sebelumnya, melatih diri untuk dapat mengidentifikasi pikiran otomatis dan menggantikannya dengan pikiran yang lebih positif, serta membuat perencanaan untuk menjaga komitmen bebas dari narkoba sehingga dapat mengurangi potensi terjadinya kekambuhan.

Menurut Melemis (2015) terapi kognitifperilaku dapat membantu meningkatkan keterampilan menyelesaikan masalah pada pengguna narkoba dan juga langkah untuk menggantikan pikiran-pikiran negatif yang selalu menjadi halangan bagi mereka dalam proses pemulihan. Hasil evaluasi menunjukkan bahwa subjek telah melakukan usaha-usaha mereka untuk menurunkan potensi mengalami kekambuhan. Melalui pemberian terapi kognitif perilaku, mereka mengasah keterampilan untuk mengatasi permasalahan yang ditemui sehari-hari di lembaga pemasyarakatan baik dengan menggantikan pikiran-pikiran negatif atau irasional, menerapkan strategi untuk mengatasi kecemasan, serta berusaha menjauhi situasisituasi yang dapat mencetuskan atau meningkatkan kemungkinan mengalami kekambuhan.

Evaluasi keseluruhan rangkaian intervensi juga menemukan bahwa ketiga subjek merasakan perubahan yaitu berkurangnya pikiran-pikiran untuk kembali menggunakan narkoba setelah mengikuti sesi intervensi. Hal ini sejalan dengan pendapat Marlatt \& Donovan (2005) yang menyatakan bahwa seorang yang sedang berada dalam proses pemulihan dari penggunaan narkoba, menceritakan pikiran-pikiran yang menekan mereka untuk kembali menggunakan narkoba kepada orang yang tepat atau pada tenaga profesional dapat mengurangi tekanan dari pikiran tersebut. Pada intervensi yang diberikan dalam penelitian ini, individu dapat mengidentifikasi dan menceritakan pikiranpikiran otomatis yang seringkali mengganggu dan menimbulkan keinginan untuk mencari narkoba dan dapat mengatasi pikiran tersebut.

\section{SIMPULAN}

Berdasarkan hasil uji hipotesis yang telah dilakukan, dapat disimpulkan bahwa terapi kognitif perilaku tidak efektif untuk menurunkan potensi kekambuhan pada narapidana mantan pecandu narkoba di salah satu lembaga pemasyarakatan di Bali. Namun jika dilihat dari rerata skor pretest dan posttest, terjadi penurunan potensi kekambuhan pada narapidana mantan pecandu narkoba, meskipun skor penurunannya tidak signifikan.

Saran bagi peneliti selanjutnya adalah peneliti dapat menambahkan sesi follow-up untuk mendiskusikan kesulitan yang ditemui subjek penelitian dalam menerapkan strategi koping yang telah dipelajari. Melalui hal ini diharapkan dapat mengoptimalkan kemampuan subjek dalam menghadapi situasi yang berisiko menimbulkan kekambuhan secara lebih signifikan. 
Untuk meminimalisir pengaruh dari pengalaman personal terhadap variabel yang diukur, disarankan agar peneliti melakukan posttest dengan jarak waktu yang tidak terlalu jauh dengan pretest. Saran yang juga dapat dilaksanakan bagi peneliti selanjutnya adalah menggunakan desain eksperimen yang dapat mengontrol pengaruh pengalaman personal seperti menggunakan kelompok kontrol dalam penelitian (Flannelly, Flannelly, \& Jankowski, 2018).

\section{DAFTAR PUSTAKA}

Badan Narkotika Nasional Republik Indonesia. (2014). Laporan kinerja instansi pemerintah badan narkotika nasional tahun 2014. Retrieved from http://bnn.go.id

Badan Narkotika Nasional Republik Indonesia. (2017). Laporan kinerja instansi pemerintah badan narkotika nasional tahun 2017. Retrieved from http://bnn.go.id

Blume, A.W. (2005). Treating drug problems. Canada: John Wiley \& Sons.

Candra, P. (2018, Agustus 29). Terbukti lakukan pemufakatan jahat narkotik, oknum sipir lapas kerobokan divonis 8 tahun penjara. Tribun Bali. Retrieved from

http://bali.tribunnews.com/2018/08/29/t erbukti-lakukan-pemufakatan-jahatnarkotik-oknum-sipir-lapas-kerobokandivonis-8-tahun-penjara

Flannelly, K.J., Flannelly, L.T., \& Jankowski, K.R.B. (2018). Threats to the internal validity of experimental and quasiexperimental research in healthcare. Journal of Health Care Chaplaincy, 24(3), 1-24.

Gutierrez, D., \& Czerny, A.B. (2017). Theory and practice of addictions counseling, chapter 10: The transtheoretical model for change. AS: SAGE Publication.
Habibi., Basri, S., \& Rahmadhani, F. (2016). Faktor-faktor yang berhubungan dengan kekambuhan pengguna narkoba pasien rehabilitasi badan narkotika nasional baddoka Makassar tahun 2015. Al-Sihah: Public Health Journal, 8(1), 1-11.

Handershot, C.S., Witkiewitz, K., George, W.H., \& Marlatt, G.A. (2011). Relapse prevention for addictive behaviors. Substance Abuse Treatment, Prevention, and Policy, 6(17), 1-17.

Irvin, J.E., Bowers, C.A., Dunn, M.E., \& Wang, M.C. (1999). Efficacy of relapse prevention: A meta-analytic review. Journal of Consulting and Clinical Psychology, 67(4), 563-570.

Isnawangsari, A.Y., Riaditya, E., \& Setiawan, T. (2015). Pengaruh alat bukti hasil tes urin melalui pemeriksaan laboratorium forensik terhadap putusan yang dijatuhkan hakim dalam tindak pidana penyalahgunaan narkotika. GEMA, (50), 1732-1745.

Jafari, E., Eskandari, H., Sohrabi, F., Delavar, A., \& Heshmati, R. (2010). Effectiveness of coping skills training in relapse prevention and resiliency enhancement in people with substance dependency. Procedia-Social and Behavioral Sciences, (5), 1376-1380. doi:10.1016/j.sbspro.2010.07.291

Kelana, S. (2018, Maret 7). Terungkap 3 tersangka narkoba beli sabu dari napi lapas kerobokan. Berita Bali. Retrieved from

https://www.beritabali.com/read/2018/0 3/07/201803070009/Terungkap-3-

Tersangka-Narkoba-Beli-Sabu-dariNapi-Lapas-Kerobokan.html

Marlatt, G.A., \& Donovan, D.M. (2005). Relapse prevention: Maintenance strategies in the treatment of addictive behaviors. New York: Guilford Press. 
Melemis, S.M. (2015). Relapse prevention and five rules of recovery. Yale Journal of Biology and Medicine, (88), 325-332.

Miller, W. R., \& Harris, R. J. (2000). A simple scale of Gorski's warning signs for relapse. Journal of Studies on Alcohol, (61), 759-765.

Neuman, W. L. (2007). Social research methods: Qualitative and quantitative approaches. US: Pearson Education.

Rambe, E.S.D. (2017). Analisa narkoba jenis morfin, amfetamin, dan THC (tetrahidrokannabinol) menggunakan strip test. Retrieved from http://repositori.usu.ac.id/handle/12345 6789/4727

Range, B.P., \& Mathias, A.C.R. (2012). Cognitive-behavior therapy for substance abuse. In I.R.D. Olivieara (Ed.), Standard and innovative strategies in cognitive behavior therapy (pp. 157-170). Croatia: Intech.

Riandini., \& Nurmaguphita, D. (2017). Hubungan dukungan keluarga dengan tingkat motivasi untuk sembuh pada penyalahguna napza di lapas narkotika kelas IIA Yogyakarta (Skripsi, Universitas 'Aisyiyah Yogyakarta, Yogyakarta, Jawa Tengah). Retireved from http://digilib.unisayogya.ac.id

Sahu, K.K., \& Sahu, S. (2012). Substance abuse causes and consequences. Bangabasi Academic Journal, 9(12), 52-59.

Sugiyono. (2012). Metode penelitian kuantitatif, kualitatif, dan $R \& D$. Bandung: Alfabeta.

Taylorwitkiewitz, S., \& Asmundson, G. (2007). Internal and external validity in clinical research. In D. Mckay (Ed.), Handbook of research methods in abnormal and clinical psychology (pp. 23-34). London: SAGE Publication.

Witkiewitz, K., \& Marlatt, G. A. (2005). Relapse prevention for alcohol and drug problems. American Psychological Association, 59 (4), 224-235. 